\title{
NGUYÊN NHÂN, ĐẠC ĐIỂM LÂM SÀNG, CẬN LÂM SÀNG SUY TIM CẤP Ở TRẺ EM
}

\author{
Ma Văn Thấm', Phạm Văn Thắng² \\ 1. Bệnh viện Đa khoa Quốc tế Vinmec; 2. Đại học Y Hà Nội
}

\begin{abstract}
TÓM TẮT
Suy tim cấp (STC) là tình trạng cơ tim mất đột ngột khả năng cung cấp lưu lượng máu nên không đáp ứng được các nhu câu chuyển hóa của cơ thể. Nguyên nhân STC đa dạng và thay đổi theo lứa tuổi, triệu chứng thường không điển hình, vì vậy khi vào cấp cứu thường ở giai đoạn nặng, tỷ lệ tử vong cao. Mục tiêu: Mô tả triệu chứng lâm sàng, cận lâm sàng và nguyên nhân STC ở trẻ em. Đối tượng nghiên cứu: gồm 70 bệnh nhân được chẩn đoán STC tại Bệnh viện Nhi Trung ương. Thời gian: 1/8/2017 - 31/8/2018. Phương pháp nghiên cứu: Mô tả cắt ngang.
\end{abstract}

Kết quả: Nhóm tuổi STC gặp nhiều nhất < 12 tháng tuổi (67,2\%), tỷ lệ nam/nữ là 1.2: 1. Nguyên nhân hàng đâu gây STC là nhóm các bệnh lý về cơ tim (80\%). Triệu chứng khởi phát STC chủ yếu là khó thở chiếm tỷ lệ 82,9\%, tím tái 52,9\%, tiếp theo là vật vã kích thích chiếm tỷ lệ trên $30 \%$, ho, khò khè 20\%, nôn 12,86\%, hôn mê 7,14\%, đau bụng và tiêu chảy 8,57\%, sốt. Bệnh nhân STC vào khoa cấp cứu Hồi sức với biểu hiện nhịp tim nhanh 98,6\%, CVP tăng 90\%, diện tim to và gan to $80 \%$, nhịp

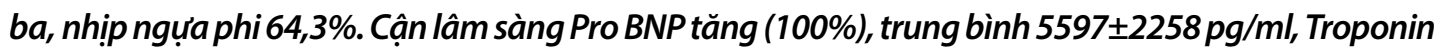
I tăng (90\%), trung bình 8,25 2 2,99 ug/l, Xquang tim to chỉ số tim ngực tăng (84,1\%), siêu âm tim phân suất tống máu EF giảm < 50\% (68,1\%). Kết luận: STC gặp chủ yếu trẻ < 12 tháng tuổi, nguyên nhân hàng đầu là nhóm bệnh lý cơ tim, triệu chứng lâm sàng đa dạng, tình trạng nặng nhập viện là suy hô hấp, suy tim nặng.

Từ khóa: Suy tim ở trẻ em, suy tim cấp ở trẻ em.

\section{ABSTRACT \\ ETIOLOGIES AND CLINICAL, PARACLINIAL CHARACTERISTICS OF ACUTE HEART FAILURE IN CHILDREN}

Acute heart failure (AHF) is a condition in which heart muscle suddenly loses its ability to ensure flow, so it is unable to meet the body's metabolic needs. Causes of AHFs vary with age, symptoms are often atypical, patient's conditions during emergency are often severe, and mortality rates are high. Objective: To describe the clinical, paraclinical and causes of AHF in children. Subjects: Including 70 patients diagnosed with AHF at the National Hospital of Pediatrics. Time: August 1, 2017 - August 31, 2018. Research method: Cross-sectionalstudy. Results: The most common age of AHF is less than 12 months old (67.2\%), the ratio of male / female is 1.2: 1 . The leading cause of AHF is the cardiomyopathy ( $80 \%)$.

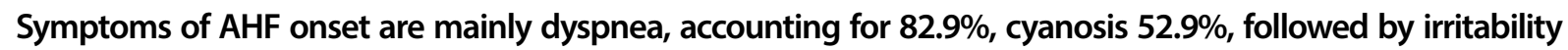
with the rate of over $30 \%$, cough, wheezing $20 \%$, vomiting $12.86 \%$, coma $7.14 \%$, abdominal pain and diarrhea $8.57 \%$, fever.

Nhận bài: 15-3-2021; Chấp nhận: 15-4-2021

Người chịu trách nhiệm chính: Phạm Văn Thắng

Địa chỉ:ĐT: 0913506336, Email: tsbsthang@yahoo.com 
The patients admitted to the emergency, the resuscitation departments with manifestations of tachycardia 98.6\%, CVP increased by $90 \%$, enlarged heart area and enlarged liver $80 \%$, triple rhythm, horse rhythm $64.3 \%$.

Upon presentation at emergency, patient presents severe acute respiratory failure that warrants intubation and mechanical ventilation (52.9\%). Increased Pro BNP (100\%), mean $5597 \pm 2258 \mathrm{pg} / \mathrm{ml}$, increased Troponin I (90\%), mean $8.25 \pm 2.99 \mathrm{ug} / \mathrm{I}$, cardiomegaly on CXR (84.1\%) ), decreased EF on 2D Echo $<50 \%$ (68.1\%). Conclusion: AHFs mainly affects children $<12$ months old, the leading cause is cardiomyopathy with various clinical symptoms, respiratory and circulatory failure requireshospitalization.

Key words: Heart failure in children, acute heart failure in children.

\section{1. ĐẶT VẤN ĐỀ}

Suy tim cấp là thuật ngữ mô tả suy tim tiến triển nhanh trong vài giờ đến vài ngày. Nguyên nhân STC ở trẻ em thay đổi theo lứa tuổi. Triệu chứng chính là suy tim trái hoặc suy tim toàn bộ nhanh chóng. Bệnh cảnh lâm sàng là một tình trạng giảm nặng cung lượng tim đột ngột mất bù. [1]

Suy tim cấp ở trẻ em làm tăng tỷ lệ tử vong, thời gian nằm viện kéo dài, tăng gánh nặng kinh tế cho gia đình và xã hội. Trên thế giới theo Solmon Gebremariam tại Ethiopia (2016), STC chiếm 2,9\% tổng số trẻ nhập viện, tuổi trung bình là 8 tuổi, tử vong xảy ra trong 19\% trường hợp trong đó75,7\% ca tử vong do AHF gặp ở trẻ $<1$ tuổi [5]. Theo Scott M. Macicek (2009) tỷ lệ tử vong do STC ở trẻ em tại Mỹ là 18\%[4]. Tại Việt Nam đã có một số công trình nghiên cứu về STC, tuy nhiên có rất ít nghiên cứu có hệ thống về STC ở trẻ em. Để góp phần cho chẩn đoán và điều trị sớm STC ở trẻ em ngay khi vào cấp cứu. Chúng tôi thực hiện đề tài với mục tiêu: "Mô tả triệu chứng lâm sàng, cận lâm sàng và nguyên nhân suy tim cấp ở trẻ em vào khoa Cấp cứu hồi sức Bệnh viện Nhi Trung ương".

\section{2. ĐốITƯợNG VÀ PHƯơNG PHÁP NGHIÊN CỬU}

\section{1.Đối tượng nghiên cứu}

- Tất cả những trẻ được chẩn đoán STC nhập viện điều trị tại khoa Cấp cứu-chống độc, khoa Hồi sức cấp cứu, Bệnh viện Nhi Trung ương. Tuổi: từ 1 tháng đến 15 tuổi.
- Trẻ được chẩn đoán suy tim cấp: Theo RD. Ross; Solmon Gebremariam [5], [6] khi có 3/4 tiêu chuẩn sau:

1. Nhịp tim nhanh so với lứa tuổi, nhịp tim $>160$ lần/phút trong giai đoạn sơ sinh và trẻ nhỏ< 24 tháng, $>140$ lần/phút ở trẻ > 2 tuổi, $>120$ lần/phút ở trẻ $>4$ tuổi và $>100$ lần/phút ở trẻ > 6 tuổi.

2. Nhịp thở nhanh so với lứa tuổi tần số thở $>60$ lần/ phút ở trẻ sơ sinh, $>40$ lần/ phút ở trẻ $<24$ tháng, > 30 lần/phút ở trẻ $2-5$ tuổi, > 28 lần/ phút ở trẻ 5 - 10 tuổi và $>25$ lần/ phút ở trẻ > 10 tuổi.

3. Diện tim to trên lâm sàng hoặc chỉ số tim ngực $>60 \%$ ở trẻ $<1$ tuổi, $>55 \%$ ở trẻ 1 - 5 tuổi và $>50 \%$ ở trẻ $>5$ tuổi.

4. Gan to mềm ít nhất $3 \mathrm{~cm}$ dưới bờ sườn phải.

- Tiêu chuẩn loại trừ: Bệnh nhân vào cấp cứu trong tình trạng ngừng tim, bệnh nhân xuất hiện STC sau phẫu thuật tim, sốc nhiễm khuẩn có tổn thương tim.

2.2. Thiết kế nghiên cứu: Mô tả cắt ngang.

2.3. Cỡ mẫu nghiên cứu: Cỡ mẫu thuận tiện.

2.4. Quy trình nghiên cứu: Bệnh nhân vào khoa được hỏi bệnh, thăm khám, yêu cầu xét nghiệm, đánh giá tình trạng nặng, tình trạng suy tim. Các biến nghiên cứu phân theo mức độ, theo tuổi so với chỉ số bình thường của trẻ em Việt Nam.

2.5. Xử lý số liệu: Xử lý số liệu bằng phần mềm SPSS 20.0.

\section{KẾT QUẢ NGHIÊN CỨU}

\section{1. Đặc điểm chung của nhóm nghiên cứu}


- Tuổi: Từ 2 tháng đến 12 tháng có 47/70 bệnh nhân chiếm tỷ lệ $67,3 \%$, tuổi từ 12 đến 60 tháng có $20 / 70$ bệnh nhân chiếm $28,6 \%$, nhóm $\geq 60$ tháng có $3 / 70$ bệnh nhân chiếm tỷ lệ 4,3\%.
- Giới: Có 38/70 bệnh nhân là nam (54,3\%) và 32/70 bệnh nhân là nữ $(45,7)$, tỷ lệ nam/nữ là 1.2 : 1 .

\section{2. Đặc điểm lâm sàng suy tim cấp}

Bảng 1. Triệu chứng khởi phát suy tim cấp trước khi vào cấp cứu

\begin{tabular}{|l|l|c|c|}
\hline \multicolumn{2}{|c|}{ Triệu chứng lâm sàng } & $\mathbf{n}(70)$ & $\%$ \\
\hline \multirow{3}{*}{ Biểu hiện tại tim mạch } & Khó thở & 58 & 82,9 \\
\cline { 2 - 4 } & Tím tái & 37 & 52,7 \\
\cline { 2 - 4 } & Dau tức ngực & 3 & 4,3 \\
\hline \multirow{5}{*}{ Biểu hiện ngoài tim } & Vật vã kích thích & 21 & 30 \\
\cline { 2 - 4 } & Co giật & 3 & 4,3 \\
\cline { 2 - 4 } & Hôn mê & 5 & 7,1 \\
\cline { 2 - 4 } & Oau bụng & 6 & 8,6 \\
\cline { 2 - 4 } & Nôn & 9 & 12,9 \\
\cline { 2 - 4 } & Tiêu chảy & 6 & 8,6 \\
\cline { 2 - 4 } & Ho, khò khè & 14 & 20 \\
\cline { 2 - 4 } & Sốt & 22 & 31,4 \\
\hline
\end{tabular}

Nhận xét: Triệu chứng khởi phát STC chủ yếu là khó thở chiếm tỷ lệ 82,9\% tiếp theo là tím tái 52,9\%, tiếp theo là sốt, vật vã kích thích chiếm tỷ lệ cao nhất trên 30\%, ho, khò khè $20 \%$, nôn $12,86 \%$, hôn mê $7,14 \%$, đau bụng và tiêu chảy $8,57 \%$.

Bảng 2. Triệu chứng lâm sàng bệnh nhân suy tim cấp khi vào cấp cứu, hồi sức

\begin{tabular}{|l|l|c|c|}
\hline \multicolumn{2}{|c|}{ Triệu chứng lâm sàng } & $\mathbf{n}(70)$ & $\%$ \\
\hline \multirow{2}{*}{$\begin{array}{l}\text { Nhịp tim } \\
\text { (lần/phút) }\end{array}$} & Nhanh & 69 & 98,6 \\
\cline { 2 - 4 } & Bình thường & 1 & 1,4 \\
\cline { 2 - 4 } & Chậm & 0 & 0 \\
\hline \multirow{2}{*}{ Diện tim to } & Có & 56 & 80 \\
\cline { 2 - 4 } & Không & 14 & 20 \\
\hline \multirow{2}{*}{ Gan to } & Có & 56 & 80 \\
\cline { 2 - 4 } & Không & 14 & 20 \\
\hline \multirow{2}{*}{ Nhịp ba hoặc nhịp ngựa phi } & Có & 45 & 64,3 \\
\cline { 2 - 4 } & Không & 25 & 35,7 \\
\hline \multirow{2}{*}{ Tiếng thổi } & Có & 14 & 20 \\
\cline { 2 - 4 } & Không & 56 & 80 \\
\hline \multirow{2}{*}{ Ran ẩm ở phổi } & Có & 17 & 24,3 \\
\cline { 2 - 4 } & Không & 53 & 75,7 \\
\hline \multirow{3}{*}{ CVP } & $<5 \mathrm{mmHg}$ & 2 & 4 \\
\cline { 2 - 4 } & $5-10 \mathrm{mmHg}$ & 3 & 90 \\
\cline { 2 - 4 } & $\geq 10 \mathrm{mmHg}$ & 45 & 24,3 \\
\hline \multirow{2}{*}{ Phản hồi gan tĩnh mạch cổ } & Có & 17 & 75,7 \\
\cline { 2 - 4 } & Không & 53 & 28,6 \\
\hline \multirow{2}{*}{ Phù } & Có & 50 & 71,4 \\
\cline { 2 - 4 } & Không & 20 & \\
\hline
\end{tabular}

Nhận xét: Bệnh nhân STC vào khoa Cấp cứu hồi sức với biểu hiện nhịp tim nhanh 98,6\%, CVP tăng $90 \%$, diện tim to và gan to $80 \%$, nhịp ba, nhịp ngựa phi $64,3 \%$, phù và ran ẩm chỉ gặp $24,3 \%$. 


\section{3. Đặc điểm cận lâm sàng suy tim cấp}

Bảng 3. Bảng một số đặc điểm Xquang, siêu âm tim, điện tim bệnh nhân STC

\begin{tabular}{|l|l|c|c|}
\hline \multicolumn{2}{|c|}{} & $\mathbf{n}(\mathbf{7 0})$ & $\%$ \\
\hline \multirow{3}{*}{ Xquang chỉ số tim ngực } & To & 58 & 84,1 \\
\cline { 2 - 4 } & Bình thường & 11 & 15,9 \\
\hline \multirow{3}{*}{ ứ huyết phổi } & Có & 19 & 27,5 \\
\cline { 2 - 4 } & Không & 50 & 72,5 \\
\hline \multirow{5}{*}{ Tiêu âm tim EF } & $\leq 40$ & 40 & 56 \\
\cline { 2 - 4 } & $40-50$ & 7 & 10,1 \\
\cline { 2 - 4 } & $\geq 50$ & 22 & 31,9 \\
\hline \multirow{5}{*}{ Điện tâm đồ } & Nặng & 3 & 4,4 \\
\cline { 2 - 4 } & Vừa & 10 & 14,5 \\
\cline { 2 - 4 } & Nhẹ & 1 & 1,5 \\
\cline { 2 - 4 } & Không & 55 & 79,6 \\
\hline & Tăng gánh buồng tim & 59 & 84,3 \\
\cline { 2 - 4 } & Cơn nhịp nhanh & 7 & 10 \\
\cline { 2 - 4 } & Loạn nhịp & 4 & 5,7 \\
\hline
\end{tabular}

Nhận xét: Bệnh nhân STC Xquang tim to chỉ số tim ngực tăng chiếm (84,1\%). Siêu âm tim phân suất tống máu giảm dưới $50 \%$ chiếm $(68,1 \%)$ trong đó có $(56 \%)$ bệnh nhân có EF giảm nặng. Điện tâm đồ tăng gánh các buồng tim (84,3\%).

Bảng 4. Một số đặc điểm marker men tim ở bệnh nhân suy tim cấp

\begin{tabular}{|l|l|c|c|c|}
\hline \multicolumn{2}{|c|}{} & $n$ & $\%$ & $\begin{array}{c}\text { Trung bình } \\
\text { X } \pm \text { SD }\end{array}$ \\
\hline \multirow{3}{*}{ Pro BNP } & $<300$ & 0 & 0 & 0 \\
\cline { 2 - 5 } & $\geq 300$ & 70 & 100 & $5597 \pm 2258$ \\
\hline \multirow{3}{*}{ Troponin I } & $<0,07$ & 7 & 10.00 & $0.038 \pm 0.018$ \\
\cline { 2 - 5 } & $\geq 0,07$ & 63 & 90.00 & $8.25 \pm 2.99$ \\
\hline \multirow{3}{*}{ CK - MB } & $<24$ & 16 & 22.86 & $17.94 \pm 3.28$ \\
\cline { 2 - 5 } & $\geq 24$ & 54 & 77.14 & $240 \pm 58.9$ \\
\hline
\end{tabular}

Nhận xét: Bệnh nhân STC vào đơn vị cấp cứu kết quả xét nghiện Pro BNP tăng trong (100\%) số bệnh nhân, trung bình $5597 \pm 2258$ pg/ml. Troponin I tăng trong (90\%) tăng trung bình 8,25 $\pm 2,99$ ug/l. 


\subsection{Nguyên nhân suy tim cấp}

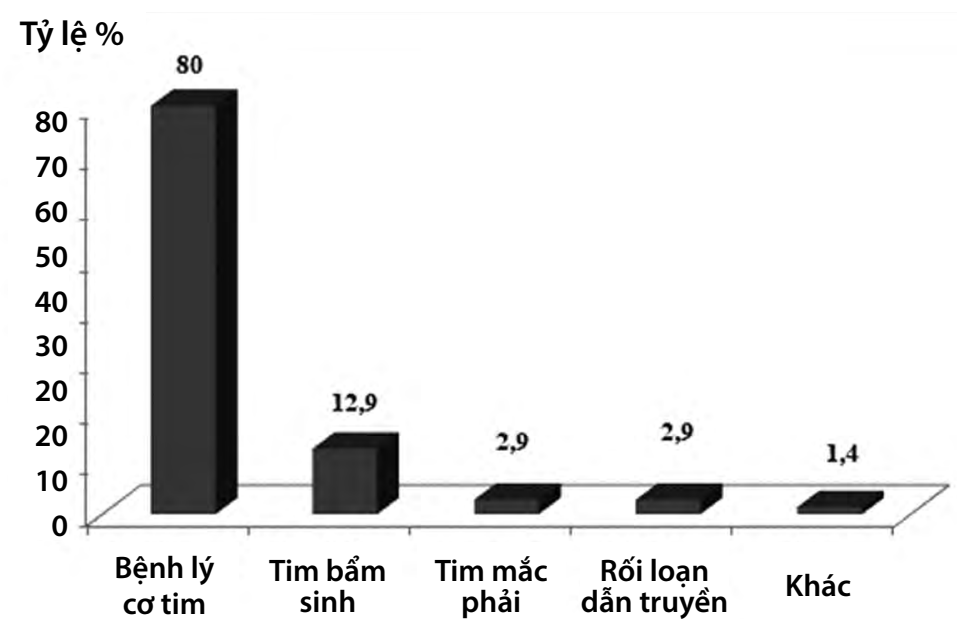

Biểu đồ 1. Phân loại theo nhóm nguyên nhân gây suy tim cấp

Nhận xét: Nguyên nhân hàng đầu STClà nhóm các bệnh lý về cơ tim chiếm tỷ lệ $80 \%$, tiếp theo là nhóm tim bẩm sinh chiếm tỷ lệ $12,9 \%$, rối loạn dẫn truyền và nhóm bệnh lý tim mắc phải $2,9 \%$, các nguyên nhân khác chiếm tỷ lệ 1,4\%.

Nguyên nhân viêm cơ tim hay gặp nhất là virus chiếm $71,0 \%$, các virus thường gặp là Coxsackie $B$, Echovirus, Adenovirus; vi khuẩn là $3 / 41$ bệnh nhân chiếm 9,7\%, các vi khuẩn thường gặp là Mycoplasma, Leptospira; bệnh nhân Kawasaki có $1 / 41$ bệnh nhân chiếm 3,2\%; không xác định được nguyên nhân chiếm $16,1 \%$.

\section{BÀN LUẬN}

\section{1. Đặc điểm chung}

Tuổi suy tim cấp gặp ở mọi lứa tuổi, nhưng gặp nhiều nhất ở trẻ dưới 60 tháng tuổi chiếm tỷ lệ. Lứa tuổi trung bình 42,7 tháng. Theo Solmon Gebremariam (2016) tại Ethiopia sự phân bố về tuổi rất đa dạng $65 \%$ STC ở trẻ > 6 tuổi và $20 \%$ ở trẻ < 3 tuổi, độ tuổi trung bình 8 tuổi [5]. Ở Việt Nam, theo nghiên cứu của Ngô Anh Vinh (2016) nghiên cứu tại Bệnh viện Nhi Trung ương thấy lứa tuổi suy tim gặp nhiều nhất 1 tháng - 5 tuổi $75 \%$, tuổi trung bình $45.32 \pm 26.37$ tháng [11].

Trẻ nam $(54,3 \%)$ và nữ $(45,7)$, tỷ lệ nam/nữ là 1.2 : 1. Nghiên cứu của Đinh Quang Tuấn (2005) tại Bệnh viện Trung ương Huế thì nữ chiếm tỷ lệ cao hơn nam là $(63,3 \%)$ tỷ lệ nam/nữ là: $1: 1.7$. Nguyễn Khắc Sơn (2003) tại Bệnh viện Trẻ em Hải Phòng thì tỷ lệ giữa 2 giới là tương đương[3].

\section{2. Đặc điểm lâm sàng}

Triệu chứng khởi phát STC chủ yếu là khó thở chiếm tỷ lệ 82,9\%, tím tái 52,9\%, tiếp vật vã kích thích chiếm tỷ lệ cao nhất trên $30 \%$, ho, khò khè $20 \%$, nôn $12.86 \%$, hôn mê $7,14 \%$, đau bụng và tiêu chảy $8,57 \%$, sốt.

Nghiên cứu của Đinh Quang Tuấn (2005) dấu hiệu khởi phát đặc trưng trong suy tim sung huyết là vã mồ hôi $76,7 \%$, thở mệt khi gắng sức $100 \%$, kém ăn $100 \%$, tiểu ít $66 \%$ [3]. Điều này cho thấy triệu chứng khởi phát suy tim cấp thường nhanh và cấp tính, đòi hỏi đánh giá phân loại nhanh và xử trí kịp thời. Ngoài ra trong nghiên cứu của chúng tôi bệnh nhân còn nhiều triệu chứng cơ năng ngoài cơ quan tim mạch như: vật vã kích thích, co giật, hôn mê. Đặc biệt bệnh nhân suy tim cấp có biểu hiện đau bụng chiếm tỷ lệ $8,6 \%$, nôn chiếm tỷ lệ $12,9 \%$, tiêu chảy chiếm tỷ lệ $8,6 \%$, ho, khò khè chiếm tỷ lệ $20 \%$, sốt chiếm tỷ lệ $31,4 \%$. Điều này trái ngược với suy tim cấp ở người lớn, các triệu chứng về cơ quan tiêu hóa rất hiếm gặp. Nhứng dấu hiệu lâm sàng này giống với viêm dạ dày, viêm ruột, khó định hướng để cha mẹ cho trẻ đi khám và nhân viên tiếp cận chẩn đoán 
và điều trị đúng suy tim cấp. Nghiên cứu của tác giả: Scott M. Macicek (2009) Hoa Kỳ buồn nôn hoặc nôn $60 \%$, tiêu chảy $18 \%$, đau bụng $36 \%$, đau ngực $24 \%$. Kết quả $26 \%$ bệnh nhân đã được bolus dịch ngay tại đơn vị cấp cứu và không được chẩn đoán suy tim cấp trước khi hội chẩn với bác sĩ chuyên khoa tim mạch tại các trung tâm hồi sức tim mạch [4].

Bệnh nhân STC vào đơn vị Cấp cứu hồi sức với biểu hiện nhịp tim nhanh $98,6 \%$, CVP tăng $90 \%$, diện tim to và gan to $80 \%$, nhịp ba, nhịp ngựa phi $64,3 \%$, phù và ran ẩm chỉ gặp $24,3 \%$.

Nghiên cứu của tác giả: Scott M. Macicek (2009) Hoa Kỳ tình trạng suy tuần hoàn cấp tính và suy hô hấp là lý do chính bệnh nhân $A H F$ vào cơ sở y tế cấp cứu, $11 \%$ bệnh nhân phải thông khí nhân tạo trước khi vào cấp cứu trong đó có $18 \%$ bệnh nhân có kết quả tử vong hoặc phải cấp cứu ngừng tuần hoàn [3]. Nghiên cứu của Nguyễn Thị Thu Hà trên bệnh nhân sốc tim, triệu chứng STC ở bệnh nhân sốc tim như mạch nhanh nhỏ, huyết áp giảm, giảm tưới máu tổ chức ( 83 - 91\%), có $91,7 \%$ bệnh nhân li bì hôn mê, suy hô hấp nặng chiếm $69,4 \%$ và phù phổi cấp $36,1 \%$ [2].

Nhịp ngựa phi xuất hiện do hiện tượng làm đầy thất quá nhanh do suy tim nặng. Có nhịp ngựa phi là dấu hiệu đặc trưng STC [1],[11],[12]. Trong nghiên cứu có 64,3\% bệnh nhân xuất hiện nhịp ngựa phi. Nghiên cứu Scott M. Macicek (2009) Hoa Kỳ bệnh nhân STC có nhịp ngựa phi là 50\% [4]. Nghiên cứu Nguyễn Thị Thu Hà (2013) nhịp ngựa phi gặp 33,3\% bệnh nhân sốc tim [2].

Trong giờ đầu vào khoa Hồi sức cấp cứu có 50 bệnh nhân được đặt catheter tĩnh mạch trung tâm theo dõi CVP. Kết quả $90 \%$ có áp lực tĩnh mạch trung tâm tăng cao $\geq 10 \mathrm{mmHg}$ biểu hiện tình trạng tăng áp lực nhĩ phải và quá tải dịch. Nghiên cứu của Nguyễn Thị Thu Hà (2013) sốc tim ở trẻ em 38,2\% bệnh nhân có CVP tăng, 29,4\% CVP bình thường và $32,4 \%$ CVP giảm [2]. Kết quả này nhóm CVP tăng ít hơn và CVP giảm nhiều hơn so với nghiên cứu của chúng tôi do ở bệnh nhân sốc tim trong nghiên cứu này chủ yếu nguyên nhân do tay chân miệng, những bệnh nhân này biểu hiện suy giảm chức năng tim nhưng đồng thời biểu hiện mất nước. Điều này giống với các nghiên cứu về tay chân miệng.

\section{3. Đặc điểm cận lâm sàng}

- Bệnh nhân STC Xquang có tim to chỉ số tim ngực tăng chiếm $(84,1 \%)$, phổi ứ huyết $27,5 \%$. Nghiên cứu của Scott M. Macicek (2009) tim to thấy trong $98 \%$, hình ảnh phù nề phế nang $58 \%$ trường hợp Xquang tim phổi ở bệnh nhân STC [4]. Nghiên cứu của Đinh Quang Tuấn (2005) tim to chiếm tỷ lệ $70 \%$ [3]. Siêu âm tim phân suất tống máu giảm dưới $50 \%$ chiếm $(68,1 \%)$ trong đó có $(58 \%)$ bệnh nhân có EF giảm nặng, tăng áp lực động mạch phổi chiếm $(20,3 \%)$ trong đó tăng áp lực động mạch phổi nặng chiếm $(4,4 \%)$. Nghiên cứu của ADHERE, tỷ lệ EF giảm là $(46 \%)$, không ghi nhận liên quan tử vong trong viện với phân suất tống máu thất trái [8]. Nghiên cứu của Scott M. Macicek (2009) 67\% bệnh nhân có phân suất tống máu giảm nặng [4]. Nghiên cứu của Nguyên Thị Thu Hà (2013) EF < 50\% chiếm 84,4\%, EF giảm nặng chiếm 40,6\% [2].

- Xét nghiệm men tim Pro BNP, troponin I, CK đều tăng cao, đặc biệt Pro BNP tăng trung bình $5597 \pm 2258$ pg/ml cao gấp 18 lần giá trị nghi ngờ suy tim. Tăng Pro BNP là hậu quả của tăng áp lực trong buồng nhĩ, tăng giải phóng các peptid bài niệu natri, một chất giãn mạch có tác dụng tăng bài tiết muối và nước. Nồng độ BNP không bị ảnh hưởng bởi một số thuốc điều trị suy tim như furosemide, digoxin, nitroglycerin... Nồng độ BNP trong máu không thay đổi trong ngày. Các nghiên cứu cho thấy nồng độ BNP thay đổi giữa các nhóm tuổi khác nhau. Theo nghiên cứu Law YM ở các trẻ khỏe mạnh từ sơ sinh đến 16 tuổi, giá trị trung bình BNP là $96 \mathrm{pg} / \mathrm{ml}$ ở nhóm tuổi sơ sinh và $22 \mathrm{pg} / \mathrm{ml}$ ở nhóm trẻ ngoài sơ sinh, ở trẻ gái $51,89 \pm 48,36 \mathrm{pg} / \mathrm{ml}$ và 44,22 \pm 27,14 pg/ml ở trẻ trai. Nghiên cứu của Zhang SR giá trị nồng độ $B N P>149,8$ pg/ml là ngưỡng giới hạn để phân biệt có suy tim hay không. Nghiên cứu của Auerbach $S R$, nồng độ $B N P \geq 140$ pg/ml là ngưỡng giới hạn bắt đầu có biểu hiện suy tim [12],[13]. Theo khuyến cáo của Hiệp hội Tim mạch châu Âu BNP $>300 \mathrm{pg} / \mathrm{ml}$ là dấu hiệu nghi ngờ STC [14]. Nghiên cứu của Ngô Anh Vinh nồng độ NT-Pro BNP ở nhóm suy tim trung bình $1125 \pm 1923,40$, nhóm không suy tim $26,74 \pm 38,79$ [11]. Wong DT et al (2011) nghiên cứu mối tương quan giữa nồng độ của tiền hormon bài niệu natri và NT - pro BNP 
với biểu hiện lâm sàng nặng và kết quả điều trị STC mất bù ở trẻ em thấy nồng độ NT - pro BNP cao nhất ngày thứ 2 - 3 sau nhập viện và giảm đi sau đó cho tới khi xuất viện, Pro BNP tăng cao có giá trị tiên lượng mức độ nặng STC [9].

\subsection{Nguyên nhân suy tim cấp}

Nguyên nhân gây STC rất đa dạng, hàng đầu gây STC là nhóm các bệnh lý về cơ tim chiếm tỷ lệ $80 \%$. Trong nhóm viêm cơ tim cấp là nguyên nhân hay gặp nhiều nhất 73,7\%. Kết quả này tương đồng tác giả Nguyễn Văn Bàng về nguyên nhân STC ở trẻ em chủ yếu là viêm cơ tim cấp và các bệnh lý gây suy giảm chức năng tim đột ngột [1]. Nghiên cứu của Nguyễn Thị Thu Hà (2013) nguyên nhân gây sốc tim đứng hàng đầu là viêm cơ tim cấp chiếm $64 \%$, tiếp theo là bệnh cơ tim giãn $14 \%$, tim bẩm sinh $11 \%$, rối loạn dẫn truyền $5 \%$. Trong đó viêm cơ tim cấp do bệnh tay chân miệng chiếm 41,7\% [2].

Sự khác biệt của các nghiên cứu này do nguyên nhân STC ở trẻ em khác nhau giữa các lứa tuổi, khu vực địa lý. Việt Nam là một nước đang phát triển nền y học ngày càng tiến bộ, mô hình bệnh tật của nước ta song song giữa các bệnh lý của các nước phát triển và các nước đang phát triển. Nhờ chương trình phòng chống thấp tim mà tỷ lệ thấp tim ở nước ta giảm thấp [1],[2]. Mặt khác có thể do các nghiên cứu này có cách thiết kế nghiên cứu khác nhau, tiêu chuẩn lựa chọn bệnh nhân khác nhau.

\section{KẾT LUÂN}

Suy tim cấp gặp chủ yếu trẻ $<12$ tháng tuổi, nguyên nhân hàng đầu là nhóm bệnh lý cơ tim, triệu chứng lâm sàng khởi phát không đầy đủ và điển hình, dễ nhầm lẫn với bệnh lý khác, khi vào viện cấp cứu với tình trạng nặng suy hô hấp, suy tim cấp điển hình về lâm sàng và cận lâm sàng. Vi vậy điều trị khó khăn, tỷ lệ tử vong cao.

\section{TÀI LIÊU THAM KHẢO}

1. Nguyễn Văn Bàng (2015), "Suy tim cấp ở trẻ em", Bài giảng nhi khoa sách đào tạo sau đại học, Nhà xuất bản Y học, Hà Nội, tr. 230 - 238.

2. Nguyễn Thị Thu Hà (2013), "Nghiên cứu nguyên nhân, một số đặc điểm lâm sàng, cận lâm sàng và nhận xét kết quả xử lý ban đầu sốc tim trẻ em tại Bệnh viện Nhi Trung ương", luận văn tốt nghiệp bác sĩ nội trú, Đại học Y Hà Nội, tr. 18 - 20.

3. Đinh Quang Tuấn (2005), “Khảo sát nguyên nhân và đánh giá diễn tiến lâm sàng trong điều trị suy tim sung huyết ở trẻ em", Tạp chí Nhi khoa tập 14 số đặc biệt 2006, tr 227 - 233.

4. Scott M. Macicek, MD, aCharles G. Macias, MD (2009) "Acute Heart Failure Syndromes in the Pediatric Emergency Department", American Academy of Pediatrics.

5. Solmon Gebremariam và Tamirat Moges (2016), "Pediatric Heart Failure, Lagging, and Sagging of Care in Low Income Settings: A Hospital Based Review of Cases in Ethiopia", Hindawi Publishing Corporation Cardiology Research and Practice Volume 2016, Article ID 7147234, 7 pages.

6. R. D. Ross, R. O. Bollinger, and W. W. Pinsky, "Grading the severity of congestive heart failure in infants," Pediatric Cardiology, vol. 13, no. 2, pp. 72-75, 1992.

7. M. U. Anah, O. E. Antia-Obong, C. O. Odigwe, and V. O. Ansa, "Heart failure among paediatric emergencies in Calabar, South Eastern Nigeria," Mary Slessor Journal of Medicine, vol. 4, no. 1, pp. 58-62, 2004.

8. Laothavorn,P., et al., Thai Acute decompensated Heart Failure Registry (Thai ADHERE). CVD Prevention and Control, 2010.5.p.89-95.

9. Wong DT et al. (2011). “Effectiveness of seriall increases in amino-terminal pro-B-type natriuretic peptide levels to indicate the need for mechanical circulatory support in children with acute decompensated heart failure", am j cardiol; 107(4); 573 - 8.

10. Tobias JD (2011), “B - type natriuretic peptide: diagnostic and therapeutic applications in infants and chidren", J Intensive Care Med 26(3): 138 - 95.

11. Ngô Anh Vinh (2015), “Nghiên cứu giá trị của peptide lợi niệu typ $B$ (NT - Pro BNP) trong chẩn đoán suy tim ở trẻ em", Tạp chí Y học Việt Nam tập 441, tháng 4 - số 2/2016, tr 109 - 113. 